\title{
Entrepreneurial Migration in an Integrated World
}

\author{
Spiros Bougheas* \\ GEP and School of Economics \\ University of Nottingham \\ Nottingham, NG7 2RD \\ United Kingdom \\ spiros.bougheas@nottingham.ac.uk \\ and \\ Rod Falvey \\ Bond Business School \\ Bond University \\ QLD 4229 \\ Australia \\ rfalvey@bond.edu.au
}

November 2016

\begin{abstract}
A growing number of developed countries are offering entrepreneurial visas as a means of attracting entrepreneurial talent and capital. In this paper we use a simple two sector model of international trade with heterogeneous agents and financial frictions to show that entrepreneurial migration can contribute to the international efficiency of production, even when capital also flows internationally through borrowing and lending and foreign direct investment. In our model all cross-border transactions are motivated by cross-country variations in the quality of financial institutions.
\end{abstract}

Keywords: entrepreneurial migration; economic integration; institutions; financial frictions

JEL Classification: F21, G15

Acknowledgements: An earlier version of the paper titled "The Impact of Financial Constraints and Wealth Inequality on International Trade Flows, Capital Movements and Entrepreneurial Migration" was published as a GEP WP 14/04, University of Nottingham. We would like to thank the Editor and three anonymous referees, Doug Nelson, Haiping Zhang and participants at the $1^{\text {st }}$ International Workshop on 'Contemporary Economic Theory: Topics on Development Economics', University of Guadalajara, 2009, the $2^{\text {nd }}$ GEP Conference in China, University of Nottingham - Ningbo, 2009, and the Australasian Trade Workshop, Sydney, 2015, for helpful comments and suggestions. The first author would like to acknowledge financial support from European Cooperation in Science and Technology Action IS1104 (GECOMPLEX).

*Corresponding Author 


\section{Introduction}

The economic contributions of migrant entrepreneurs are increasingly being recognised as evidenced by the recent attempts of many national governments to attract them. Table 1 provides a sample of visa programmes specifically targeting entrepreneurial migrants. ${ }^{1}$ In addition, many European countries, including France, Germany, Italy, the Netherlands, Spain, Denmark, and Sweden, offer self-employed immigrant visas with conditions and eligibility criteria that vary by country. Entrepreneurial migrants are generally expected to play an active role in managing their enterprise and the requirements for permanent residency often include job creation. The underlying motivation is that governments want to boost entrepreneurship in general, because (successful) entrepreneurship is expected to create jobs and to bring other economic benefits (innovation for example, see $\mathrm{Xu}, 2015$ ). The argument for specific entrepreneurial visas, is that standard work visas, which are otherwise used to attract skilled and talented individuals, might exclude potential entrepreneurs. Work visas typically involve education and skill qualifications which may not be necessary for successful entrepreneurship in some areas, and often require employer sponsorship which constrains immigrants from starting their own businesses until permanent residency has been achieved. In the meantime the business opportunity and/or the potential migrant may have gone elsewhere (see Sumption, 2012).

Although, the numbers entering on entrepreneurial migrant visas are not large $\mathrm{e}^{2}$ there is ample evidence suggesting that a significant number of migrants establish their own firms. A recent report $(\mathrm{OECD}, 2010)$ notes that in the majority of OECD countries the share of workers in self-employment is higher among immigrants than among the native born. A more recent study (Marchand and Siegel, 2014) finds that the corresponding shares for members of the European Union are slightly higher for citizens $(12.2 \%)$ than it is for non-citizens $(10.5 \%)$. However, there is significant variation in the likelihood of being self-employed across countries for both types of residents. In the extremes we have Greece where 24.4 per cent of citizens are self-employed in contrast to only 6.5 per cent of non-citizens and the Czech Republic where 27.8 per cent of non-citizens are self-employment in contrast to 15.1 per cent of citizens.

Migration experts have observed that despite the growing trend of entrepreneurial migration there is lack of research on its potential effects (see e.g. Kerr, 2013; Marchand and

\footnotetext{
${ }^{1}$ This list does not even exhaust the business/entrepreneurial visas available from these countries. Australia, for example, also has: Investor, Significant Investor, Venture Capital Entrepreneur and Significant Business History visa streams.

${ }^{2}$ For example the Australian scheme listed in Table 1 had 739 applications lodged and 342 granted in 2013/1014; and the UK Entrepreneur visa scheme granted 1156 visas in 2013-14.
} 
Siegel, 2014). All countries mentioned above are well-integrated into the world economy. Goods, capital and firms are allowed to move relatively freely across their borders. If we view entrepreneurial migration as providing a new channel for capital movements in addition to international borrowing and lending and foreign direct investment (FDI), the question arises of: what are the additional benefits of entrepreneurial migration for such economies? Or, put differently, what are the additional gains from trade due to entrepreneurial migration ${ }^{3}$

Drawing a distinction between entrepreneurial migration and FDI provides us with several options, since both involve an entrepreneur from one country producing in the other, and we base our distinction on the existence (FDI) or absence (entrepreneurial migration) of retained links with the source country. Conventionally, FDI occurs when a 'firm' located in one country owns and controls production in another. Thus in our model FDI occurs when an agent who is an eligible entrepreneur in her domestic country, chooses to produce in the other country, conditional on being an eligible entrepreneur there also, while retaining a production link with her domestic country. The production link can be either the use of the source county technology in production in the host market or the borrowing of capital from the source market and subject to its financial institutions. We assume that the investing firm has full access to the host property rights protection, and that the foreign investor's income is transferred to and spent in the source country. Entrepreneurial migration is then the migration of an agent (along with her assets), to act as an entrepreneur in the other country. The entrepreneurial migrant effectively severs all economic ties with the source country - capital is borrowed in the host; the investment is subject to the host financial system and property rights; and the entrepreneur's income is spent in the host. In summary, in our model FDI gives entrepreneurs access to property rights protection in the host country while retaining access to source country finance. Migration puts entrepreneurs under the host country property rights and financial regimes.

A well-established literature has identified the quality of financial institutions as an important determinant of trade patterns and the direction of the flows of capital and FDI. ${ }^{4}$ This is because the capacity of a country's institutions to mitigate the effects of market frictions (such as informational asymmetries between lenders and borrowers, poor quality corporate

\footnotetext{
${ }^{3}$ We recognise that in practice governments might have a variety of motives for encouraging entrepreneurial migration that are not captured by our model, such as attracting talent, creating new jobs, boosting economic growth and broadening the tax base. Our aim is not to explain why governments offer entrepreneurial visas per se, but to explore why there is even scope for entrepreneurial migration in countries that are already well integrated into the world economy.

${ }^{4}$ For evidence on the impact of the quality of financial institutions, see, for example, Beck (2002) and Manova (2013) for trade patterns, Alfaro et al. (2008) for capital flows and Antras et al. (2009) for FDI. Property rights protection also depends on the quality of the judicial institutions. Aizenman and Spiegel (2006) and Nunn (2007) have examined their implications for international trade and FDI.
} 
governance and property rights) impacts on the ability of its entrepreneurs to borrow. In a global economy cross-country differences in the quality of institutions act as a new source of comparative advantage affecting the movements of goods, capital and firms across borders.

Building on this literature, we construct a very simple two factor, two-good model, in which differences in the quality of financial institutions generate incentives for international goods trade, international borrowing and lending, FDI and entrepreneurial migration to occur simultaneously. Products are homogeneous, but economic agents are heterogeneous in their capital ownership. ${ }^{5}$ We first introduce trade in goods, borrowing and lending and FDI. To keep the analysis simple we do not model different types of transaction costs and policy barriers. ${ }^{6}$ Instead we ask "having allowed for trade, international borrowing and lending and FDI, is there any scope for entrepreneurial migration?" and if so "how does it change the equilibrium?" 7

In our model the main incentive for entrepreneurs to migrate is access to better quality financial institutions. We recognize that, as many experts have observed (see OECD (2010) and Marchand and Siegel (2014)) that it is much more difficult for migrants to access financial markets in the destination country than it is for native citizens. There is some evidence from the United States, for example, that shows that controlling for credit-worthiness, ethnic minorities are much more likely to be denied credit as other applicants and when they obtain credit they do so at higher interest rates (Blanchflower et al., 2003; Blanchflower, 2009). But these facts are also due to the higher failure rates of firms run by immigrants and also due to the immigrants' lack of credit histories in the country of residence (Bruder et al., 2011). We will show that these observations are not inconsistent with our model.

But despite these difficulties many migrants manage to receive bank loans. For example, Albareto and Mistrulli (2011) analyzing a large sample of Italian firms conclude that the gap between the interest rates charged on loans granted to migrants and those on loans offered to native citizens narrows significantly as credit history lengthens. In their study of German firms,

\footnotetext{
${ }^{5}$ The same type of model has been used by Bougheas and Riezman (2007) to examine the effects of changes in the distribution of human capital endowments on the patterns of trade and by Davidson and Matusz (2006) and Davidson, Matusz and Nelson (2006) to examine compensation policies for those who lose with the introduction of trade liberalization. In an earlier version of their work, Ju and Wei (2006) consider a modified two-sector, Heckscher-Ohlin model which includes entrepreneurial heterogeneity in terms of their cost of exerting effort.

${ }^{6}$ The advantage of not modeling transactions costs is that our analysis can be conducted in a relatively clear and straightforward fashion. The drawback is that the equilibrium can be driven to corner solutions. Given that we are assuming costless free trade in goods, there are no 'market access' advantages in locating production in any particular market. This, combined with the free movement of capital and entrepreneurial labor means that all the production of the capital intensive good can end up in one location.

${ }^{7}$ Clearly our approach tends to minimise the potential role of entrepreneurial migration, since such migration is only allowed to occur once the scope for financial capital flows and FDI have been exhausted, and migrants are assumed to sever all links with the source country. Much of the FDI that occurs in our model could be replaced by entrepreneurial migration if barriers to investment were relatively higher.
} 
Bruder et al. (2011) find that although it is significantly more difficult for migrants to obtain credit $58 \%$ of the immigrants but only $39 \%$ of the native Germans were either denied a loan or received a smaller amount than what they requested) still $26 \%$ of the ethnic-minorities' startups, where offered bank loans.

In Section 2, we model the potential inefficiencies introduced by institutional frictions through the existence of two alternative technologies for producing the capital-intensive good. The less efficient technology has constant returns to scale and does not require recourse to the financial markets. The more efficient technology has a fixed scale, is risky and requires the labor of an entrepreneur. Frictions limit the ability of entrepreneurs to raise funds in a competitive financial market. In modelling financial constraints we use the fixed investment version of the Holmstrom and Tirole (1997) model. The ability of agents to choose their level of effort, which is unobservable by investors, limits the amount of income that the former can pledge to the latter and thus the amount of external funds that they can obtain. Agents are free to choose their sector of employment, a decision that ultimately depends on their initial endowments of physical assets. Depending on the parameters of the model, we can have either a partial specialization equilibrium, where both technologies are used and thus only a fraction of agents specialize, or a complete specialization equilibrium where all agents produce only one good. Under the former equilibrium the economy is financially constrained as there are insufficient agents who satisfy the personal wealth constraint necessary to become active entrepreneurs to ensure that all the economy's capital stock is employed efficiently. In contrast, under complete specialization what limits the production of the capital-intensive good is the level of aggregate wealth. ${ }^{8}$

Given that we want to understand how differences in the quality of financial institutions can affect entrepreneurial migration, we consider two countries with identical technologies and endowments but which differ in the quality of their financial institutions. We start from an autarky equilibrium in which one country is fully specialized and the other country is partially specialized. In Section 3 we then investigate the effects of international trade, international capital mobility and FDI. Then, in Section 4, we introduce entrepreneurial migration.

In accordance with the rest of the literature we demonstrate that better institutions encourage the export of goods produced by financially dependent sectors (in our case, the

\footnotetext{
${ }^{8}$ Similar equilibria are also derived in Ju and Wei (2011). In their work when financial constraints do not bind comparative advantage is determined by technological factors, while when these constraints bind the quality of institutions matter for comparative advantage.
} 
capital-intensive sector). ${ }^{9}$ There is also empirical support for the assertion that financial constraints have an influence on trade patterns. ${ }^{10}$ International borrowing and lending involves asset holders in one country lending (the use of) their capital to entrepreneurs in the other. ${ }^{11}$ Capital will flow away from the country with the poor quality of financial institutions till interest rates in the two countries are equalized. We also find that FDI flows to countries with higher quality institutions that offer better protection of property rights. A similar result is obtained by Antras et al. (2009). ${ }^{12}$ These results are in contrast to those obtained by Ju and Wei (2006, 2010) who examine the implications of cross country differences in the quality of financial institutions for international capital flows. Their major result is to show that financial globalization allows an inefficient financial system and weak corporate governance to be bypassed by a combination of inward foreign direct investment and outward financial capital flows. Thus, in their model FDI and capital flows move in opposite directions while in the present paper they move in the same direction. The reason for the difference in the predictions is that in our model, as in Antras et al. (2009), FDI is attracted by better property rights protection while in Ju and Wei $(2010,2011)$ it is attracted by higher capital productivity. Given that both motivations are likely to be present in practice, it is perhaps not surprising that the empirical evidence on this is mixed. Antras et al. (2009) provide empirical support for their model, while Forbes (2010) and Prasad et al. (2006) provide evidence supporting Ju and Wei (2010, 2011). In particular, Antras et al. (2009) find that weaker investor protection rights decrease the presence of multinational activity and make the remaining multinational firms more reliant financially on their parent companies. Similar conclusions are reached by Aleksynska and Havrylchyk (2013) who compare the impact of institutional quality on FDI investors from the North and the South. ${ }^{13}$

\footnotetext{
${ }^{9}$ An observation made by Antras and Caballero (2009), Beck (2002), Chaney (2005), Egger and Keuschnigg (2009), Foellmi and Oechslin (2010), Furusawa and Yanagawa (2011), Ju and Wei (2011), Kletzer and Bardhan (1987), Manova (2013), Matsuyama (2005) and Wynne (2005).

${ }^{10}$ Manova (2008) finds that financial liberalization increases exports disproportionately more in sectors that are financially vulnerable. Similarly, Manova (2013) finds that financially developed countries export a wider variety of products in financially vulnerable sectors. Similar conclusions are in Beck (2003), Hur, Raj and Riyanto (2006) and Svaleryd and Vlachos (2006).

${ }^{11}$ To keep the analysis simple, we have opted for a static framework (see also Ju and Wei, 2011). The main advantage of a dynamic analysis is that it allows a distinction between financial capital and physical capital. However, Antras and Caballero (2009), by developing a dynamic version of their main static model have shown that the two approaches yield similar predictions.

${ }^{12}$ Antras et al. (2009) distinguish between multinational firm activity and FDI. The former is similar to the definition of FDI in our model. They make the distinction because they allow for co-ownership of projects and thus they want to separate the level of investment financed internally from the level of foreign ownership.

${ }^{13}$ They state "We confirm earlier findings in the literature for investors from the North by showing that they are consistently deterred by a larger institutional difference between FDI source and destination countries. ... Those investors from the South that invest in countries with better institutions choose countries with the best possible institutions, thus giving preference to larger positive institutional distance. Despite unfamiliarity, such an
} 
As we will see below, in our model, entrepreneurial migration flows in the same direction as FDI. It seems that our choice of modelling FDI leaves less room for entrepreneurial migration given that both are driven by similar factors. Thus, if such migration is a feature of the equilibrium in our model it is plausible that it would also be featured in a model with the alternative specification of FDI.

We complete the model by introducing entrepreneurial migration in Section 4. The difference in quality of institutions between the two countries creates a wedge between the thresholds that separate those agents that become entrepreneurs from those agents that produce the labor-intensive good. Clearly, the threshold is lower in the country with the better quality institutions and this offers incentives to those agents in the other country with endowments between the two thresholds to migrate. We show that entrepreneurial migration survives in an equilibrium where all forms of capital movements are allowed and find that at the new equilibrium FDI and migration are weak substitutes.

Our approach has parallels with Schmitt and Soubeyran (2006) who employ a onesector model to explain two-way flows of highly skilled migrants - referred to as 'brain circulation'. In their model production requires the services of an entrepreneur and workers and, as in our model, the choice between these two occupations is endogenously determined. Migrants can be workers or entrepreneurs and their equilibrium depends on cross-country technological differences. Like us, Schmitt and Soubeyran (2006) find that some agents switch activities when migration is allowed. However, while their focus is exclusively on migration generated by technology differences, our focus is on cross-country differences in the quality of financial institutions that determine not only entrepreneurial returns but also the ability to become an entrepreneur.

Section 5 concludes.

\section{The Closed-Economy Model}

There is a continuum of agents of measure 1 each endowed with one unit of labor. The only source of heterogeneity among them is their endowments of assets (capital) $A$ which are uniformly distributed on the unit interval. ${ }^{14}$ The economy produces two final goods - a

institutional environment is the most transparent for potential entrants due to low corruption, sound property rights, and political stability." (p.39)

${ }^{14}$ Alternatively, we could have considered financial frictions in a model where heterogeneity arises because of differences in productivity (see, for example, Buera et al., 2011, Moll, 2014). In a static framework this choice is not consequential. 
manufacturing product (MAN) and a primary commodity (PRI). All agents are risk-neutral, have homothetic preferences and allocate equal shares of their income on each good.

Production of one unit of PRI requires one unit of labor. There are two technologies available for producing MAN. The first, the safe technology, is a constant returns technology that requires one unit of assets for each unit of production. The second, the advanced technology, is stochastic and needs an entrepreneur who uses her labor endowment to manage it. The advanced technology requires a fixed investment of $K>1$ units of capital and yields $R$ units of MAN when it succeeds and 0 when it fails. ${ }^{15}$ Following the Holmström and Tirole (1997) model we assume that the probability of success depends on the behavior of the entrepreneur. When the entrepreneur exerts effort the probability of success is $p_{H}=\lambda$, while when she shirks the probability of success is $p_{L}=0$; however, in the latter case she derives an additional benefit $B .{ }^{16} \mathrm{We}$ assume that when the entrepreneur exerts effort net benefits are positive $(\lambda R>K)$, and negative otherwise $(B<K)$. Put differently, projects are socially efficient only in the case where the entrepreneur exerts effort. We follow Ju and Wei (2006, 2010) and interpret a higher value of $\lambda$ as better property rights protection (or a lower risk of expropriation or a lower tax on output); and a higher $B$ as weaker corporate governance.

In this economy agents have the following three choices. Firstly, they can use their labor to produce one unit of PRI and invest their assets in the safe technology. Secondly, they can use their labor to produce one unit of PRI and lend their assets to entrepreneurs. Thirdly, they can become entrepreneurs and borrow additional assets from lenders.

\subsection{The Financial Contract}

The derivation of the financial contract is based on the fixed-investment case in Holmström and Tirole (1997). The financial market is competitive and lenders make zero profits. Under the assumption that borrowers are protected by limited liability, the financial contract specifies that the two parties receive nothing when the project fails. Let $R_{b}$ denote the entrepreneur's payoff otherwise. Then an entrepreneur will exert effort if the incentive compatibility constraint

\footnotetext{
${ }^{15}$ So PRI is labor-intensive and MAN is capital-intensive. Taking the limiting cases on factor inputs greatly simplifies the determination of factor prices and our results are consistent with those obtained when both sectors use both factors. See Egger and Keuschnigg (2009) and Wynne (2005) for example. The restriction of constant marginal productivity of capital is of no great consequence given our static environment. For some important dynamic effects see von Hagen and Zhang (2014).

${ }^{16}$ This is how Tirole (2006) interprets B: "The entrepreneur can "behave" ("work", "exert effort", "take no private benefit") or "misbehave" ("shirk", "take a private benefit"); or equivalently, the entrepreneur chooses between a project with a high probability of success and another project which ceteris paribus she prefers (is easier to implement, is more fun, has greater spinoffs in the future for the entrepreneur, benefits a friend, delivers perks, is more "glamorous," etc.) but has a lower probability of success." (p. 115)
} 


$$
\lambda R_{b} \geq B
$$

is satisfied. This constraint sets a minimum on the entrepreneur's payoff which is the measure of agency costs. For a given contract the entrepreneur has a higher incentive to exert effort the larger the probability of success $(\lambda)$ and the lower the benefit from shirking $(B)$. The constraint also implies that the maximum (expected) amount that the entrepreneur can pledge to the lender is $(\lambda R-B)$. Consider an entrepreneur with initial wealth $A$. Then the lender's zero-profit condition for a loan to this entrepreneur, under the assumption that the borrower has an incentive to exert effort, is given by

$$
\lambda\left(R-R_{b}\right)=r(K-A)
$$

where $r$ denotes the equilibrium interest rate. The left-hand side is equal to the expected return of the lender and the right-hand side is equal to the opportunity cost of the loan.

\subsection{Financial Market Equilibrium}

Substituting the incentive compatibility constraint as an equality in the zero-profit condition gives a threshold on physical assets $\left(A_{0}\right)$ that entrepreneurs must be endowed with in order to obtain external finance and thus take advantage of the high-return advanced technology -i.e.

$$
A_{0}=K-\frac{1}{r}(\lambda R-B)=K-\frac{\gamma}{r}
$$

Where $\gamma \equiv \lambda R-B$, is equal to the maximum pledge that entrepreneurs can make to lenders. The number of active entrepreneurs/projects/firms in an economy is then determined by either the number of eligible entrepreneurs (the 'financing constraint') or the total assets available for borrowing (the 'wealth constraint'). Each constraint generates an associated entrepreneurial (asset) threshold. Given that agents always have the option to invest their assets in the safe technology, the equilibrium interest rate must satisfy $r \geq 1$. The entrepreneurial threshold under the financing constraint $\left(A_{f}\right)$, is derived by setting $r=1$ in (1) as

$$
A_{f}=K-\gamma
$$

This threshold depends on the investment technology and the quality of the country's financial institutions through the maximum pledge. Given the investment size $K$ and the total assets available $\int_{0}^{1} A d A=\frac{1}{2}$ (the economy's wealth), the number (mass) of active entrepreneurs when all assets are invested in the risky technology is $\frac{1}{2 K}$. The entrepreneurial threshold under the wealth constraint $\left(A_{w}\right)$ then satisfies 


$$
1-A_{w}=\frac{1}{2 K}
$$

where $1-A_{w}$ is the mass of agents with asset holdings greater than or equal to $A_{w}$. Rewriting this equation as $\left(1-A_{w}\right) K=\frac{1}{2}$ we obtain the market-clearing equilibrium condition where the lefthand side now shows the total demand for funds by eligible entrepreneurs. Solving for the threshold we get

$$
A_{w}=1-\frac{1}{2 K} \equiv \delta
$$

This threshold depends on the country's average asset holdings. Using (3) and (1) we can solve for the equilibrium interest rate when the wealth constraint is binding:

$$
r=\frac{\gamma}{K-1+\frac{1}{2 K}}=\frac{\gamma}{K-\delta}
$$

We can now define the two types of equilibria that can occur in this model:

Definition 1 - Complete Occupational Specialization Equilibrium (COSE): An equilibrium where the wealth constraint is binding and the equilibrium interest rate adjusts so that $A_{0}=A_{w}>A_{f}$ with $r=\frac{\gamma}{K-\delta} \geq 1$.

When the economy is in a COSE, all producers of the primary commodity invest their assets in the financial market. Only entrepreneurs produce the manufacturing product. Here the imperfections in the capital market do not affect the allocation efficiency of the economy as all capital is invested in the advanced technology.

Definition 2 - Partial Occupational Specialization Equilibrium (POSE): In this case $\frac{\gamma}{K-\delta}<1$, the financing constraint is binding and $A_{0}=A_{f}>A_{w}$, with $r=1$.

Now financial imperfections do affect allocation efficiency and some assets are invested in the safe technology.

\subsection{Goods Market Equilibrium}

Without any loss of generality we use MAN as the numeraire and let $P$ be the relative price of PRI. We denote the output of PRI by x, and the output of MAN by $y$. Then

$$
x=A_{0} \text { and } y=\left[1-A_{0}\right] \lambda R+\left\{\frac{1}{2}-\left[1-A_{0}\right] K\right\}
$$


PRI output depends on the number of agents working in the PRI sector, while MAN output can have two components - the output produced using the advanced technology plus any output produced using the safe technology (if the country is in a POSE). The value of PRI output is $P x=P A_{0}$, and aggregate income is given by $\frac{r}{2}+[\lambda R-r K]\left[1-A_{0}\right]+P A_{0}$, where the first term is equal to total interest income and $\lambda R-r K$ is the payment for entrepreneurship, and is the same for all active entrepreneurs. Since half of income is spent on PRI, we can use (5) to solve for

$$
P=\frac{\frac{r}{2}+(\lambda R-r K)\left[1-A_{0}\right]}{A_{0}}=\frac{y}{x}
$$

In a COSE, (6) simplifies to

$$
P_{w}=\lambda R \frac{1}{2 K-1}
$$

When the economy is not financially constrained, the relative price depends only on technology. However in a POSE $(r=1),(6)$ becomes

$$
P_{f}=\frac{\frac{1}{2}+(\lambda R-K)\left[1-A_{f}\right]}{A_{f}}=\frac{\frac{1}{2}+(\lambda R-K)[1-(K-\gamma)]}{K-\gamma}
$$

If the financial constraint is binding, the relative price now depends also on the wealth distribution and the level of agency costs.

With regard to agent's incomes, an agent with asset holdings below the threshold works in the PRI sector and lends her capital, generating total (numeraire) earnings of $P+r A$, which is increasing in both $P$ (the 'wage') and the interest rate. An agent with sufficient assets to be an active entrepreneur earns $\lambda R-r[K-A]$, which is decreasing in $r$ and is unaffected by $P$. Comparing these we see that the 'rent' from the entrepreneurial option is $\lambda R-r K-P$, which is the same for all entrepreneurs and is decreasing in both the interest and wage rates.

\section{Trade, Capital Mobility and FDI (TCF)}

We now consider international trade flows, international borrowing and lending and FDI between two such economies. We deal with these transactions simultaneously because their effects are familiar from the literature. The resulting equilibrium will provide a base from which we can add entrepreneurial migration. We assume the two countries have the same distributions of wealth and population, but that the home country has superior institutions stronger property rights $\left(\lambda>\lambda^{*}\right)$ and better corporate governance $\left(B^{*}>B\right)$, where foreign country variables and parameters are denoted by $*$. We start from an autarky equilibrium where 
one country is financially constrained and the other is not. ${ }^{17}$ Given that the distribution of asset holdings is assumed to be the same in the two countries, the home country has more eligible entrepreneurs at any common interest rate (see (12) below), so that if only one country is financially constrained it must be the foreign country. Then from (2)

$$
A_{f}=K-\gamma<A_{f}^{*}=K-\gamma^{*} \text { and } A_{w}=A_{w}^{*}=\delta
$$

An autarky equilibrium where the foreign country has a POSE and the home country a COSE is possible as long as

$$
1-A_{f}>\frac{1}{2 K}>1-A_{f}^{*} \quad \text { or } \quad \gamma>K-\delta>\gamma^{*}
$$

The first inequality implies the home country has a 'surplus' of eligible entrepreneurs when its interest rate is unity, and hence the home country's equilibrium interest rate under autarky exceeds the lower bound $\left(r_{a}>1\right)$ to ration the investment opportunities. ${ }^{18}$ The second inequality implies that the foreign country has a 'shortage' of eligible entrepreneurs even when its interest rate is at its lower bound $\left(r_{a}^{*}=1\right)$. We illustrate the possible autarky outcomes in Figure 1. Since we assume $\gamma>\gamma^{*}$, the relevant range is under the $45^{\circ}$ line, and can be divided into three areas. When both pledges are low (both $<K-\delta$ ), both countries are in a POSE; when both pledges are high (both $>K-\delta$ ), both countries are in a COSE, and in the intermediate ranges $\left(\gamma>K-\delta>\gamma^{*}\right)$ the home country has a COSE and the foreign a POSE.

Given $K$ and the distribution of wealth, $K-\delta\left(=K-A_{w}\right)$ measures the minimum pledge necessary for there to be sufficient eligible entrepreneurs to employ all the available capital under the advanced technology. From (4) we get

$$
r_{a}=\frac{\gamma}{K-\delta}>r_{a}^{*}=1
$$

where to the right of the first equality sign we have the ratio of the maximum to the minimum pledge.

International trade will equalise relative product prices (at $P_{i}$, say) and international capital movements will equalise interest rates (at $r_{i}$, say). Since trade alone does not affect

\footnotetext{
${ }^{17}$ Given that our objective is to understand how differences in the quality of institutions affect the flows of entrepreneurial migration, the case where one country is wealth constrained while the other is financially constrained is of most interest. When both countries are wealth constrained the role of financial institutions is minimal. When both countries are financially constrained their interest rates under autarky are equal, and while the analysis for that case yields some interesting results when economic integration alters the type of equilibrium in one country,, the comparative statics are similar to those derived above.

${ }^{18}$ Note that 'a' is a mnemonic for 'autarky'. Later ' $\mathrm{i}$ ' will indicate integration (TCF) and 'e' integration plus entrepreneurial migration.
} 
interest rates in this model, ${ }^{19}$ once international borrowing and lending are possible capital will flow from the foreign to the home country until both interest rates are equalised at $r_{i} \geq 1$, with the inequality holding if the capital outflow releases the foreign country from its financial constraint before the home interest rate has fallen to unity.

FDI occurs when an eligible entrepreneur ('firm') in one country produces in the other country, but continues to use the source country technology or to borrow in the source country, and where the entrepreneurial income is repatriated to the source country. Home firms will not find FDI attractive because of the foreign country's weaker property rights regime and the fact that interest rates are equalised by capital mobility. But foreign entrepreneurs will perceive FDI as attractive as it gives them access to the stronger home property rights regime. ${ }^{20}$ The opportunity for foreign firms to access the superior home regime through FDI, while continuing to borrow in the foreign (source) market, increases their maximum pledge from $\gamma^{*}$ to $\gamma^{*}+\Delta \lambda$ (where $\Delta \lambda=\lambda-\lambda^{*}$ ) and this in itself reduces the foreign entrepreneurial threshold. ${ }^{21}$ Although these firms all produce in the home country, they use resources exclusively from their source market, and hence have no direct effect on the home capital market.

Foreign agents eligible to borrow in the foreign country, undertake FDI and produce in the home country using the home technology as long as $A \geq K-\frac{1}{r_{i}}\left[\lambda R-B^{*}\right]$. Since $K-$ $\frac{1}{r_{i}}\left[\lambda^{*} R-B^{*}\right]>K-\frac{1}{r_{i}}\left[\lambda R-B^{*}\right]$, all foreign firms that would have been active in the absence of FDI are eligible to invest abroad. Let $L_{i}^{*}$ denote the total lending by the foreign country to home firms. The thresholds $\left(A_{i}, A_{i}^{*}\right)$ and interest rate $\left(r_{i}\right)$ must now satisfy:

$$
\begin{array}{ll}
A_{i}=K-\frac{\gamma}{r_{i}} \quad \text { and } & A_{i}^{*}=K-\frac{\gamma^{*}+\Delta \lambda}{r_{i}} \\
1-A_{i}=\frac{1}{2 K}+\frac{L_{i}^{*}}{K} & \text { and } \quad 1-A_{i}^{*} \leq \frac{1}{2 K}-\frac{L_{i}^{*}}{K}
\end{array}
$$

\footnotetext{
${ }^{19}$ Because the marginal product of capital is constant. In models where trade affects the marginal product of capital, as for example in Furusawa and Yanagawa (2011), the interest rate will increase in the country with the higher quality financial institutions and decline in the other country thus reinforcing the results of this model.

${ }^{20}$ Our supposition that foreign firms can take full advantage of the property rights in the home country is extreme but without any consequence for our qualitative results. Aizenman and Spiegel (2006) consider the implications for FDI and trade when firms investing abroad cannot take full advantage of the property rights in the host country. ${ }^{21}$ The key requirement here is what it means to be 'an eligible entrepreneur in the source county'. If the source market views the eligibility of the agent using both source property rights and source corporate governance, then FDI would leave thresholds in both countries unaffected. This case would leave maximum scope for entrepreneurial migration. But given that the FDI firm's output will be subject to the host country property rights regime, we have opted to allow it and the source corporate governance to determine source country eligibility for an entrepreneur undertaking FDI. Thresholds are then affected by FDI. Alternatively we could allow source eligibility to be determined by both host property rights and host corporate governance, leaving minimum scope (i.e. none) for entrepreneurial migration.
} 
with the inequality in (13) holding if the equalised interest rate is unity.

From (12) we see that at the common interest rate we have

$$
A_{i}^{*}-A_{i}=\frac{1}{r_{i}}\left\{\gamma-\gamma^{*}-\Delta \lambda\right\}>0
$$

that is the home country has the lower threshold because of its more efficient institutions (its higher pledge).

\subsection{TCF-POSE Equilibrium}

In this case, economic integration is not sufficient to relax the financing constraint and thus remove the shortage of foreign entrepreneurs. Setting $r_{i}=1$ in (12) and (13) we get:

$$
\begin{array}{ll}
A_{i}=K-\gamma \quad \text { and } & A_{i}^{*}=K-\left[\gamma^{*}+\Delta \lambda\right] \\
{[K-\delta]+\frac{L_{i}^{*}}{K}=\gamma} & \text { and } \quad[K-\delta]-\frac{L_{i}^{*}}{K} \geq \gamma^{*}+\Delta \lambda
\end{array}
$$

This TCF-POSE equilibrium holds if $\frac{1}{K} \geq\left[K-A_{i}\right]+\left[K-A_{i}^{*}\right]$, i.e. there are insufficient eligible entrepreneurs in both countries combined to employ all the capital under the advanced technology, even when the equalised interest rate is unity. Using (16) the condition can be written as $2[K-\delta] \geq \gamma+\gamma^{*}+\Delta \lambda=2 \gamma-\Delta B$, where $\Delta B=B^{*}-B>0$.

We assume that the interest income on foreign loans and income earned from FDI is remitted in units of MAN the output that the capital/FDI produces. The home country will experience an inflow of capital and large outflows of MAN output on service account.- Once we take this repatriated income into account, it is the home income share rather than its output share that determines the direction of trade in goods. The home country will also be a net exporter of MAN and an importer of PRI output (see Appendix A1).

\subsection{TCF-COSE Equilibrium}

When as a result economic integration the financing constraint is not binding anymore we have a TCF-COSE with $r_{i}>1$. Our solutions become

$$
\begin{aligned}
& A_{i}=\delta-\frac{L_{i}^{*}}{K} \quad \text { and } \quad A_{i}^{*}=\delta+\frac{L_{i}^{*}}{K} \\
& \frac{L_{i}^{*}}{K}=\frac{\Delta B}{\gamma+\gamma^{*}+\Delta \lambda}[K-\delta] \quad \text { and } \quad r_{i}=\frac{\gamma+\gamma^{*}+\Delta \lambda}{2[K-\delta]}>1 \\
& {[K-\delta]+\frac{L_{i}^{*}}{K}=\frac{\gamma}{r_{i}}<\gamma \text { and } \quad[K-\delta]-\frac{L_{i}^{*}}{K}=\frac{\gamma^{*}+\Delta \lambda}{r_{i}}}
\end{aligned}
$$


In this case FDI and international capital movements are partial substitutes. Now all MAN output is produced using the advanced technology. Still, the patterns of capital flows, FDI flows and trade flows (see Appendix A2) are the same as before.

\subsection{Institutions and Globalization}

Our model predicts that FDI is a substitute for trade. The prediction is not new, however, the explanation is. There is a large literature analysing the relationship between FDI and international trade that suggests that horizontal FDI is a substitute for trade while vertical FDI is a complement (Blonigen, 2001). However, FDI and trade in that literature are driven by technology and endowment differences between countries and are influenced by trade costs and barriers that are absent here. In our model FDI and trade are driven by differences in the quality of financial institutions. In particular, FDI is horizontal but here the (foreign) firms engaged in this activity belong to the importing sector. The substitution effect in our model is driven by the repatriated income generated by FDI firms.

As we discussed in the introduction the fact that in our model FDI and capital flows are determined by the quality of institutions also accounts for the prediction that both move in the same direction, as in Antras et al. (2009), while in Ju and Wei (2006, 2010), where they are driven by technological differences, they move in opposite directions. However, there is also an important difference between our work and Antras et al. (2009). Their model accounts for the large FDI inflows in developing countries. In particular, they show that FDI provides a means for avoiding the host country's poor financial development. In our model, the only difference between countries lies in the qualities of their financial institutions. Among otherwise similar countries, FDI is attracted to destinations with better functioning financial markets. This is consistent with the empirical evidence provided by Alfaro et al. (2004).

\section{Entrepreneurial Migration in a Globalized World (TCFE)}

We now allow entrepreneurial migration. Given that in any equilibrium relative prices and interest rates are equalized and given that the home country has better protection of property rights all those entrepreneurs who are eligible to undertake FDI are indifferent between FDI and migrating. To break this deadlock we assume that, other things equal, agents have a preference for residing in their country of origin. Foreign agents with asset holdings in the range $\left(A_{i}^{*}, A_{i}\right)$, who are not eligible entrepreneurs in their domestic market and who cannot therefore become firms and undertake FDI, will have an incentive to migrate to the home 
country where their asset holdings do allow them to become entrepreneurs. ${ }^{22}$ Adding entrepreneurial migration leads to all agents with asset holdings above the minimum of the two entrepreneurial thresholds becoming entrepreneurs somewhere. In equilibrium all foreign agents in the range $\left(A_{e}^{*}, A_{e}\right)$ migrate to become entrepreneurs in the home country. ${ }^{23}$ The thresholds for the two financial systems are:

$$
A_{e}=K-\frac{\gamma}{r_{e}} \quad \text { and } \quad A_{e}^{*}=K-\frac{\gamma^{*}+\Delta \lambda}{r_{e}} \quad \text { where } \quad A_{e}^{*}-A_{e}=\frac{\Delta B}{r_{e}}
$$

Let $n_{e}^{*}$ denote the number of foreign entrepreneurs that migrate. Then

$$
n_{e}^{*}=A_{e}^{*}-A_{e}=\frac{\Delta B}{r_{e}}
$$

The following result describes the impact of entrepreneurial migration on the global financial market equilibrium:

Proposition 1: In the post-migration equilibrium both countries are in a COSE.

Proof: The total wealth of the migrants is given by $\int_{A_{e}}^{A_{e}^{*}} A d A=\frac{\left\{\left[A_{e}^{*}\right]^{2}-\left[A_{e}\right]^{2}\right\}}{2}=\frac{\Delta B}{r_{e}}\left\{\frac{A_{e}^{*}+A_{e}}{2}\right\}$. Their average wealth is $\left\{\frac{A_{e}^{*}+A_{e}}{2}\right\}=A_{e}+\frac{\Delta B}{2 r_{e}}$, and their average borrowing is therefore $l_{e}^{*}=K-$ $\left[A_{e}+\frac{\Delta B}{2 r_{e}}\right]$. Using $L_{e}^{*}$ to denote any international lending by the foreign country, we can write the capital market equilibrium conditions in the two countries as

$$
\left[1-A_{e}\right]+n_{e}^{*}=\frac{1}{2 K}+\frac{L_{e}^{*}+n_{e}^{*}\left[K-l_{e}^{*}\right]}{K} \quad \text { and } \quad\left[1-A_{e}^{*}\right] \leq \frac{1}{2 K}-\frac{L_{e}^{*}+n_{e}^{*}\left[K-l_{e}^{*}\right]}{K}
$$

Substituting $n_{e}^{*}$ from (21), and letting $M^{*} \equiv L_{e}^{*}-n_{e}^{*} l_{e}^{*}$ these equations simplify to

$$
\begin{aligned}
& {[K-\delta]+\frac{M^{*}}{K}=\frac{\gamma}{r_{e}}<\gamma} \\
& {[K-\delta]-\frac{M^{*}}{K} \geq \frac{\gamma^{*}+\Delta \lambda+\Delta B}{r_{e}}}
\end{aligned}
$$

An equilibrium where both countries are in a POSE (i.e. $r_{e}=1$ ) requires that

$$
2[K-\delta] \geq \gamma+\gamma^{*}+\Delta \lambda+\Delta B=2 \gamma
$$

\footnotetext{
${ }^{22}$ These agents migrate to become entrepreneurs in the other country. This should be distinguished from the phenomenon of credit constrained agents migrating temporarily in order to accumulate assets so that they satisfy the asset threshold when they return to their home country. See, for example, Mensard (2004).

${ }^{23}$ Notice that the average migrant is more financially constrained than the average native entrepreneur. To simplify the exposition of the model we have ignored other financial market frictions that might be ameliorated by higher levels internal funds, such as other types of moral hazard problems, adverse selection, etc. Such considerations would introduce some uncertainty in funding and as immigrants are more financially constrained they would be less likely to receive funding (Albareto and Mistrulli, 2011; Bruder et al., 2011)
} 
Which is inconsistent with our assumption that $\gamma>K-\delta$ in the initial equilibrium. So for the full range of pledges that we are considering both countries are in a COSE in the post-migration equilibrium.

If the home institutional quality was sufficient to give it a COSE in autarky, then, given that the two countries have the same wealth, access by the foreign firms and agents to the home property rights through FDI and to the home corporate governance and financial markets through entrepreneurial migration are sufficient to generate a COSE in the foreign country.

In order to appreciate the impact of entrepreneurial migration we need to consider two cases depending on the type of equilibrium we have in its absence.

\subsection{TCF-COSE and TCFE-COSE Equilibrium}

We begin by considering the case when before entrepreneurial migration the global equilibrium was COSE. Taking the equality in (23), we can solve for

$$
\begin{aligned}
& r_{e}=\frac{\gamma}{K-\delta}>r_{i}>1 \\
& A_{e}=K-\frac{\gamma}{r_{e}}=\delta \quad \text { and } \quad A_{e}^{*}=A_{e}+\frac{\Delta B}{r_{e}}=\delta+\frac{\Delta B}{\gamma}[K-\delta]
\end{aligned}
$$

Substituting for $r_{e}$ in (22) (or (23)) we find that in equilibrium $\frac{M^{*}}{K}=0$; or $L_{e}^{*}=n_{e}^{*} l_{e}^{*}$. That is the aggregate borrowing by foreign migrant entrepreneurs in the home market is equal to the aggregate lending by the foreign country in the home market. It is as if the migrants brought their full capital requirements with them. Recalling that foreign migrants do not meet the entrepreneurial threshold in the foreign market (i.e. $A<A_{e}^{*}$ ), it must be the case that migrants borrow more than foreign FDI firms and home firms on average.

The influx of entrepreneurial migrants has increased the entrepreneurial threshold in the home country relative to the TCF-COSE $\left(A_{e}>A_{i}\right)$. Similarly, comparing (17) and (25), we find that $A_{e}^{*}>A_{i}^{*}$ so the number of foreign firms falls. Entrepreneurial migration reduces FDI. But now $A_{e}^{*}$ simply defines the border between foreign firms undertaking FDI and foreign agents emigrating to become entrepreneurs. The effective foreign entrepreneurial threshold, which will determine which agents work in the PRI sector, is $A_{e}$, and $A_{e}=\delta<A_{i}^{*}$. So PRI output increases in the home country and falls in the foreign country, relative to the TCF-COSE, although aggregate PRI output is unchanged.

$$
x_{e}=A_{e}=x_{e}^{*}=\delta ; x_{e}>x_{i} ; x_{e}^{*}<x_{i}^{*} \text { and } X_{e}=X_{i}
$$


All MAN production takes place in the home country under the home property rights regime. The MAN outputs are the same as in the TCF-COSE

$$
y_{e}=\lambda R \frac{1}{K}=y_{i} \quad \text { and } \quad y_{e}^{*}=0=y_{i}^{*} \quad \text { and } \quad Y_{e}=\lambda R \frac{1}{K}=Y_{i}
$$

The equilibrium world relative price is unchanged since aggregate outputs are unchanged $P_{e}=$ $P_{i}$

In summary, the output effects of introducing entrepreneurial migration are confined to a transfer of PRI production to the home from the foreign country, and some rearrangement of the agents undertaking MAN production. The influx of migrant entrepreneurs crowds out some home entrepreneurs who now fall below the new common entrepreneurial threshold (those in the range $A_{i}$ to $A_{e}$ ), and some foreign entrepreneurs who would have undertaken FDI in the TCF-COSE now become migrants (those in the range $A_{i}^{*}$ to $A_{e}^{*}$ ).

The home country remains an exporter of MAN, because it has had an inflow of factors specific to MAN output. While we have shown that entrepreneurial migration (partially) substitutes for FDI, there are no clear substitutability or complementarity relationships between entrepreneurial migration and goods trade or international borrowing and lending. Borrowing by the home country, which is equal in value to the borrowing by its immigrant entrepreneurs, may be greater or less than its borrowing in the TCF-COSE (see Appendix A3). Lastly, given that aggregate outputs are unchanged, entrepreneurial migration has no impact on global production efficiency in this case. But the increase in the interest rate has transferred income from borrowers (entrepreneurs) to lenders. The migrants have gained access to the entrepreneurial rent. The displaced host entrepreneurs have lost it.

\subsection{TCF-POSE and TCFE-COSE Equilibrium}

Where entrepreneurial migration will have an impact on aggregate outputs is for those cases that generate a TCF-POSE but a TCFE-COSE - i.e. where $2 \gamma>2[K-\delta]>\gamma+\gamma^{*}+\Delta \lambda$. Again the home threshold rises $\left(A_{e}-A_{i}=\gamma-[K-\delta]>0\right)$, the foreign threshold also rises

$\left(A_{e}^{*}-A_{i}^{*}=[\gamma-\Delta B]\left\{1-\frac{[K-\delta]}{\gamma}\right\}>0\right)$, and the number of agents working in the foreign PRI sector falls (as $A_{i}^{*}-A_{e}=[K-\delta]-\left[\gamma^{*}+\Delta \lambda\right]>0$ in this range). Home output of PRI rises and foreign output of PRI falls. Home output of MAN rises and foreign output of MAN falls. Using (9), (A9) and (27) it is straightforward to show that $Y_{i}<Y_{e}$ and

$$
X_{i}-X_{e}=2[K-\delta]-\left[\gamma+\gamma^{*}+\Delta \lambda\right]>0 .
$$


in this range. We conclude that $P_{e}>P_{i}$ in this case. Once again there is no clear substitutability or complementarity relationship between entrepreneurial migration and goods trade or international borrowing and lending (see Appendix A4). However, now the switch of equilibrium implies that there are efficiency gains in production as MAN is only produced with the advanced technology. Both the wage and the interest rate increase, raising the (numeraire) income of lenders, reducing the income of entrepreneurs and the entrepreneurial rent. Again the new entrepreneurs gain access to the entrepreneurial rent at the expense of the displaced entrepreneurs.

\subsection{Institutions and Entrepreneurial Migration}

In Section 3 we have shown that cross-country variations in property rights protection and in the quality of corporate governance can be part of the explanation behind the flows of goods, capital and FDI across national borders. By affecting the ability of entrepreneurs to raise funds externally, such institutional variations prove to be sources of comparative advantage in addition to those attributed to differences in endowments and technologies. In this section, we have allowed for migration of entrepreneurs in a two-country world where goods, capital and FDI can already move freely. The following proposition summarizes our results thus far concerning the impact of entrepreneurial migration on the two countries.

Proposition 2: The introduction of entrepreneurial migration to a two-country world where goods, capital and FDI already move freely across borders leads to:

(a) Agents in the country with the weaker institutions emigrating to become entrepreneurs;

(b) An increased mass of entrepreneurs from the source country. Entrepreneurial migration crowds out some domestic entrepreneurs in the host.

(c) A higher world interest rate;

(d) A weakly higher world relative price of PRI; ${ }^{24}$

(e) Continued MAN exports by the migrant host, because the migrating factors are specific to the MAN sector;

(f) A reduced number of firms undertaking FDI. Entrepreneurial migration is a substitute for FDI.

Proof: See above and Appendices A3 and A4.

\footnotetext{
${ }^{24}$ The qualifier 'weakly' is added because when the original equilibrium is COSE the relative price remains unchanged.
} 
In their study Schmitt and Soubeyran (2006) analyse entrepreneurial migration in a model where there is no role for international capital markets and FDI. According to Proposition 2 entrepreneurial migration not only survives the introduction of these aspects of globalization but also it flows in the same direction as they do, namely, towards countries with higher quality financial institutions.

In our analysis, we have assumed that the home country has superior financial institutions, that is both better protection of property rights $\left(\lambda>\lambda^{*}\right)$ and better corporate governance $\left(B^{*}>B\right)$. In Proposition 3 below we isolate the impact of each of these two parameters on entrepreneurial migration. While we still assume that the home country has superior institutions we examine separately their marginal impact.

\section{Proposition 3: (Institutions and Entrepreneurial Migration)}

(a) An improvement in the host country's property rights (increase in $\lambda$ ) will reduce entrepreneurial migration;

(b) An improvement in the host country's corporate governance (decrease in B) will increase entrepreneurial migration;

(c) An improvement in the source country's property rights (increase in $\lambda^{*}$ ) will have no effect on entrepreneurial migration; and

(d) An improvement in the source country's corporate governance (decrease in $B^{*}$ ) will reduce entrepreneurial migration.

Proof: Substituting (24) into (21), we obtain the expression for the number of migrant entrepreneurs in terms of the financial institutional variables

$$
n_{e}^{*}=A_{e}^{*}-A_{e}=\frac{\Delta B}{r_{e}}=\frac{B^{*}-B}{\lambda R-B}[K-\delta]
$$

Then (a), (c) and (d) follow from inspection of (28). For (b) we note that

$$
\operatorname{sign}\left(\frac{\partial n_{e}^{*}}{\partial B}\right)=\operatorname{sign}\left(-\left[\lambda R-B^{*}\right]\right)<0 \text { since } \lambda R>\lambda^{*} R>B^{*} .
$$

In our model $\lambda$ and $\lambda^{*}$ capture the level of property rights protection accorded to firms in the MAN sector in the two countries. Changes in these parameters impact on FDI as foreign entrepreneurs take advantage of the better property rights protection regime in the home country. Property rights in the home country have an indirect effect on entrepreneurial migration through their impact on the world interest rate. In the new equilibrium the interest 
rate does not depend on the profitability of the MAN sector in Foreign as all production has moved abroad.

In contrast changes in the quality of corporate governance (as captured by variations in $B$ and $B^{*}$ ) have a direct impact on entrepreneurial migration. The higher the difference in the two parameters the higher is the mass of financially constrained agents in the foreign country that can access the financial markets in the home country. For the home country a change in the quality of corporate governance has also a counterbalancing effect due to its impact on the interest rate, and this effect tends to dominate.

\section{Concluding Comments}

Our aim in this paper has been to investigate the effects of adding entrepreneurial migration to a substantially globalized world economy. We introduced financial frictions into a simple two sector economy and then considered the implications of allowing free trade of goods and international borrowing and lending and foreign direct investment before introducing entrepreneurial migration across international borders. Following the earlier literature, we find that the quality of institutions, as measured here by the ability of the system to overcome a moral hazard problem that limits the amount of income which borrowers can pledge to lenders, can influence a country's trade patterns and capital movements. Our main result has been to demonstrate that there are circumstances under which entrepreneurial migration can make a contribution to global efficiency, even when goods markets are fully integrated and there is international capital market integration through borrowing, lending and foreign direct investment.

In doing this we confirmed the presumption that countries with stronger institutions export the output of financially dependent sectors, and that this comparative advantage tends to be strengthened by any capital movements. We also confirmed that capital tends to move to the country with the stronger institutions and that FDI motivated by differences in property rights flowed in the same direction as the financial capital.

When we added entrepreneurial migration, we found that it too flowed towards the country with the stronger institutions. Given its 'residual' role in our analysis, the entrepreneurial migration was restricted to what we might call 'career-changing' migrants agents who do not meet the higher entrepreneurial threshold in the country with the weaker institutions, but who do satisfy the lower threshold in the country with the stronger 
institutions. ${ }^{25}$ If the costs of FDI were sufficiently high, some agents who meet the criteria to borrow in both markets might also choose the migration option. Entrepreneurial migration and FDI were found to be substitutes. Some migrants would otherwise have undertaken FDI. Entrepreneurial migration also crowds out some domestic entrepreneurs.

Although the combination of all three forms of capital mobility eventually fully integrated the capital market and removed any distortions due to the weak institutions in one country, this did not occur through the bypass channels (financial capital outflow and FDI inflow in the country with the weaker institutions) highlighted in Ju and Wei (2010). ${ }^{26}$ Moreover, the complete removal of distortions would not hold had we assumed that both countries were financially constrained (POSE) under autarky.

We have employed a very simple model with familiar features that allowed us to obtain our results quite straightforwardly. There are numerous features that could be added. A potentially fruitful possibility for future research would be to introduce financial intermediaries. In our model all borrowing and lending takes place in capital markets. ${ }^{27}$ This is not very realistic, especially for developing economies, as a great part of financial transactions are intermediated. The introduction of financial intermediaries would allow us to examine the behavior of the spread between borrowing and lending rates which itself is a measure of financial development. The idea here is that a more efficient banking system offers higher returns on lending and lowers borrowing costs. In addition, they extend credit to agents that otherwise would have been unable to finance their projects. We would therefore expect the quality of the banking system to be another factor influencing trade patterns and the direction and volume of capital and entrepreneurial migration flows.

\footnotetext{
${ }^{25}$ In some instances, these agents may not qualify as entrepreneurial migrants. Because of concerns about bogus migrants, many entrepreneurial migration schemes have initial-entry requirements that potential migrants demonstrate their entrepreneurial ability and/or their capacity to attract funds (e.g. from venture capitalists or financial institutions which are also likely to look for experience and demonstrated success). While existing active entrepreneurs should have few difficulties in this respect, career-changing migrants have no such-experience and may therefore be ineligible under some entrepreneurial visa schemes. See Sumption (2012) for details.

${ }^{26}$ This can be attributed to the fact that in their model FDI is attracted by higher marginal productivity of capital while in our model is driven by better protection of property rights. Moreover, in our two sector model the internationally immobile factor can be employed outside the financially dependent sector, and in our case its employment in that sector doesn't require any capital at all. But in a standard, competitive one-sector model, some capital must be employed along with the labor.

${ }^{27}$ Our contractual structure is too simple to allow for a distinction between equity and bond markets. As Tirole (2006) shows by allowing the technology return to be positive when the project fails the optimal financial instrument becomes the standard debt contract.
} 


\section{References}

J. Aizenman and M. Spiegel, 2006, Institutional efficiency, monitoring costs and the investment share of FDI, Review of international Economics 14, 683-697

G. Albareto and E. Mistrulli, 2011, Bridging the gap between migrants and the banking system, Bank of Italy Working Paper 794

M. Aleksynska and O. Havrylchyk, 2013, FDI from the south: The role of institutional distance and natural resources, European Journal of Political Economy 29, 38-53

L. Alfaro, A. Chanda, S. Kalemli-Ozcan and S. Sayek, 2004, FDI and economic growth: the role of local financial markets, Journal of International Economics 64, 89-112

L. Alfaro, S. Kalemli-Ozcan and V. Volosovych, 2008, Why doesn't capital flow from rich to poor countries? An empirical investigation, Review of Economics and Statistics 90, 347-368

P. Antras and R. Caballero, 2009, Trade and capital flows: A financial frictions perspective, Journal of Political Economy 117, 701-744

P. Antras, M. Desai and F. Foley, 2009, FDI flows and multinational firm activity, Quarterly Journal of Economics, 124, 1171-1219

T. Beck, 2002, Financial development and international trade: Is there a link? Journal of International Economics 57, 107-131

T. Beck, 2003, Financial dependence and international trade, Review of International Economics 11, 296-316

D. Blanchflower, 2009, Minority self-employment in the United States and the impact of affirmative action programs, Annals of Finance 5, 361-396

D. Blanchflower, P. Levine and D. Zimmerman, 2003, Discrimination in the small-business credit market, Review of Economics and Statistics 85, 930-943

B. Blonigen, 2001, In search of substitution between foreign production and exports, Journal of International Economics 53, 81-104

S. Bougheas and R. Riezman, 2007, Trade and the distribution of human capital, Journal of International Economics 73, 421-433

J. Bruder, D. Neuberger and S. Räthke-Döppner, 2011, Financial constraints of ethnic entrepreneurship: evidence from Germany, International Journal of Entrepreneurial Behavior and Research 17, 296 - 313

F. Buera, J. Kaboski and Y. Shin, 2011, Finance and development: A tale of two sectors, American Economic Review 101, 1964-2002 
T. Chaney, 2005, Liquidity constrained exporters, University of Chicago, mimeo

C. Davidson and S. Matusz, 2006, Trade liberalization and compensation, International Economic Review 47, 723-747

C. Davidson, S. Matusz and D. Nelson, 2006, Can compensation save free trade, Journal of International Economics 71, 167-186

P. Egger and C. Keuschnigg, 2009, Corporate finance and comparative advantage, University of Munich, mimeo

R. Foellmi and M. Oechslin, 2010, Market imperfections, wealth inequality and the distribution of trade gains, Journal of International Economics 81, 15-25

K. Forbes, 2010, Why do foreigners invest in the United States? Journal of International Economics 80, 3-21.

T. Furusawa and N. Yanagawa, 2011, International trade and capital movements under financial imperfection, Hitotsubashi University mimeo.

B. Holmström and J. Tirole, 1997, Financial intermediation, loanable funds, and the real sector, Quarterly Journal of Economics 112, 663-692

J. Hur, M. Raj. and Y. Riyanto, 2006, The impact of financial development and asset tangibility on export, World Development 34, 1728-1741

J. Ju and S.-J. Wei, 2006, A solution to two paradoxes of international capital flows, IMF Working Paper WP/06/178.

J. Ju and S.-J. Wei, 2010, Domestic institutions and the bypass effect of financial globalization, American Economic Journal: Economic Policy 2, 173-204

J. Ju and S.-J. Wei, 2011, When is quality of financial system a source of comparative advantage, Journal of International Economics 84, 178-187

W. Kerr, 2013, U.S. high-killed immigration, innovation, and entrepreneurship: Empirical approaches and evidence, paper presented at the World Intellectual Property

Organisation (WIPO) Experts Meeting on 'Intellectual Property, the International Mobility of Knowledge Workers and the Brain Drain\|', Geneva

K. Kletzer and P. Bardhan, 1987, Credit markets and patterns of international trade, Journal of Development Economics 27, 57-70

K. Manova, 2008, Credit constraints, equity market liberalizations and international trade, Journal of International Economics 76, 33-47

K. Manova, 2013, Credit constraints, heterogeneous firms, and international trade, Review of Economic Studies, 80, 711-744

K. Marchand and M. Siegel, 2014, Immigrant entrepreneurship in cities, background paper 
for the World Migration Report 2015, International Organization for Migration

K. Matsuyama, 2005, Credit market imperfections and patterns of international trade and capital flows, Journal of the European Economic Association 3, 714-723

A. Mensard, 2004, Temporary migration and capital market imperfections, Oxford Economic Papers 56, 242-262

B. Moll, 2014, Productivity losses from financial frictions: Can self-financing undo capital misallocation? American Economic Review 104, 3186-3221

N. Nunn, 2007, Relationship-specificity, incomplete contracts, and the pattern of international trade, Quarterly Journal of Economics 122, 569-600

OECD, 2010, Entrepreneurship and migrants, Report by the OECD Working Party on SMEs and Entrepreneurship, OECD

E. Prasad, R. Rajan and A. Subramanian, 2006, Patterns of international capital flows and their implication for economic development, Jackson Hole Conference Paper, Federal Reserve Bank of Kansas

N. Schmitt and A. Soubeyran, 2006, A simple model of brain circulation, Journal of International Economics, 69, 296-309

M. Sumption, 2012, Visas for entrepreneurs: How countries are seeking out immigrant job creators, Migration Information Source, June 13. Migrant Policy Institute

H. Svaleryd and J. Vlachos, 2005, Financial markets, the pattern of industrial specialization and comparative advantage: Evidence from OECD countries, European Economic Review 49, 113-144

J. Tirole, 2006, The Theory of Corporate Finance, Princeton University Press, Princeton

J. von Hagen and H. Zhang, 2014. Financial development, international capital flows, and aggregate output, Journal of Development Economics 106, 66-77

J. Wynne, 2005, Wealth as a determinant of comparative advantage, American Economic Review 95, 226-254

R. Xu, 2015, High-skilled migration and global innovation, Stanford University, Mimeo 


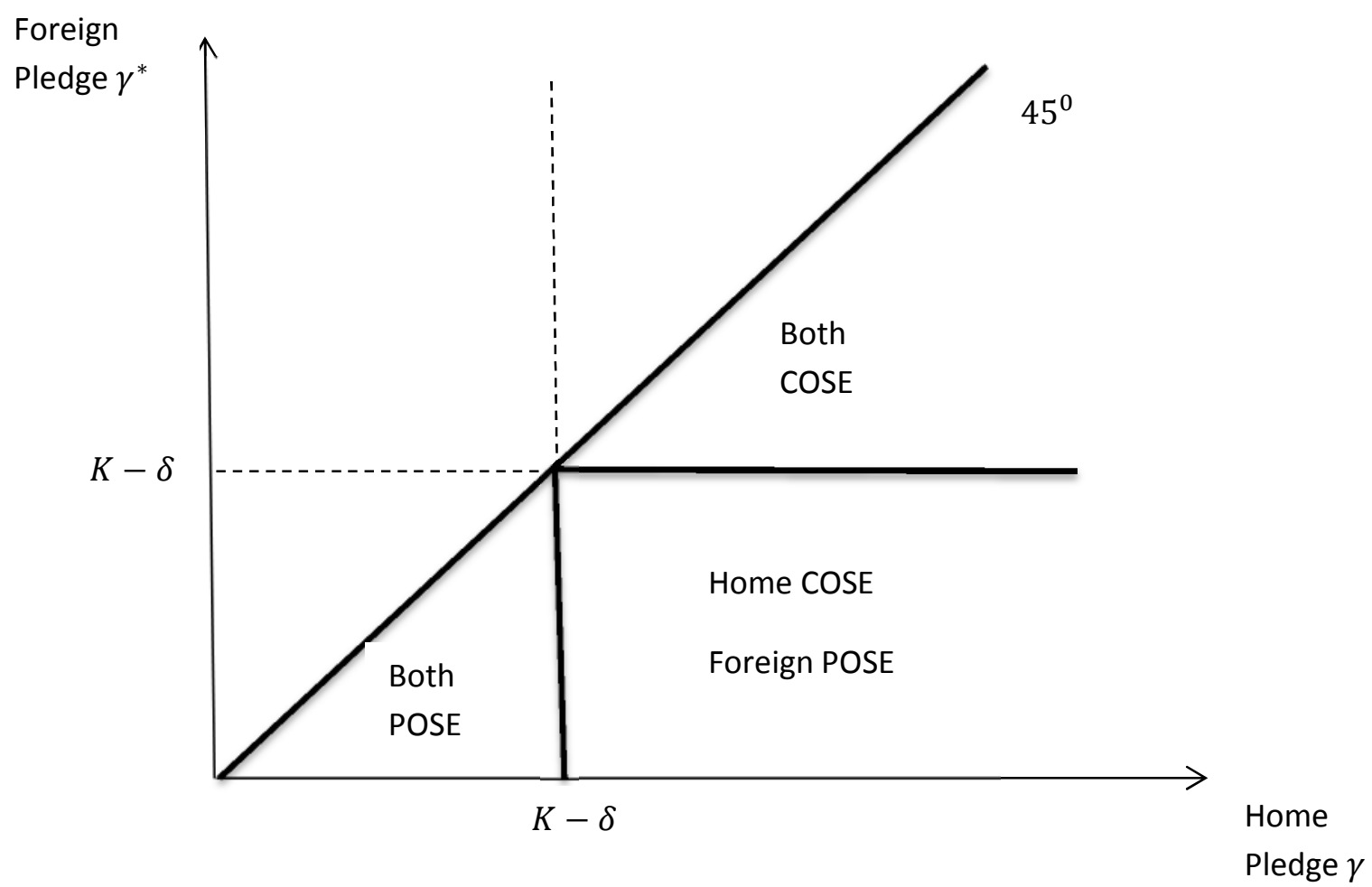

Figure 1: Autarky Equilibrium Possibilities 


\section{Appendix: Production, Income and Trade Patterns.}

\section{A1: TCF-POSE Equilibrium}

In each country PRI is produced by all agents below the corresponding threshold. In the home country MAN is produced by all agents above the two thresholds. Eligible entrepreneurs in the foreign country use FDI to produce in the home country. MAN is produced in the foreign country using the safe technology, and this output is derived by subtracting capital outflows $\left(L_{I}^{*}\right)$ and FDI $\left(\left[1-A_{i}^{*}\right] K\right)$ from the foreign country's aggregate endowment.

$$
\begin{aligned}
& x_{i}=A_{i}=K-\gamma \text { and } x_{i}^{*}=A_{i}^{*}=K-\left[\gamma^{*}+\Delta \lambda\right] \\
& y_{i}=\left[1-A_{i}\right] \lambda R+\left[1-A_{i}^{*}\right] \lambda R \text { and } y_{i}^{*}=\frac{1}{2}-L_{i}^{*}-\left[1-A_{i}^{*}\right] K
\end{aligned}
$$

The foreign threshold is higher than the home threshold, which implies that the FDI entrepreneurs (firms) borrow less, on average, than home entrepreneurs. World output is given by:

$$
\begin{aligned}
& X_{i}=2 K-\left[\gamma+\gamma^{*}+\Delta \lambda\right] \\
& Y_{i}=\lambda R \frac{1}{K}-\left\{\frac{1}{2 K}-\frac{L_{i}^{*}}{K}-\left[1-A_{i}^{*}\right]\right\}[\lambda R-K]
\end{aligned}
$$

where the second term on the RHS of (A4) represents the 'shortage' of foreign entrepreneurs multiplied by the MAN output foregone (per investment) by using the safe technology rather than the more efficient advanced technology in the home country.

The equilibrium world relative price is given by $P_{i}=\frac{Y_{i}}{X_{i}}$. The home country will export MAN if its (income) share of world MAN output exceeds its (income) share of world PRI output $\left(S_{i}^{y}>S_{i}^{x}\right)$. Home income from MAN $\left(I_{i}\right)$ is equal to home MAN output less the interest payments to foreign lenders. Foreign income from MAN $\left(I_{i}^{*}\right)$ is equal to the aggregate income of its capital plus the income of its entrepreneurs (remember the interest rate is equal to the return of the safe technology which is equal to one).

$$
\begin{aligned}
& I_{i}=\left[1-A_{i}\right] \lambda R-L_{i}^{*} \\
& I_{i}^{*}=\frac{1}{2}+\left[1-A_{i}^{*}\right][\lambda R-K]
\end{aligned}
$$

Considering the home income shares, we have $S_{i}^{y}=\frac{I_{i}}{I_{i}+I_{i}^{*}}$ and $S_{i}^{x}=\frac{[K-\gamma]}{\left[K-\gamma+K-\gamma^{*}-\Delta \lambda\right]}$. Thus, 


$$
S_{i}^{y}-S_{i}^{x}=\frac{\left[K-\left(\gamma^{*}+\Delta \lambda\right)\right] I_{i}-[K-\gamma] I_{i}^{*}}{\left[I_{i}+I_{i}^{*}\right]\left[2 K-\left[\gamma+\gamma^{*}+\Delta \lambda\right]\right]}>0
$$

since $\gamma>\gamma^{*}+\Delta \lambda$ and $I_{i}>I_{i}^{*}$. So besides the large outflows of MAN output on service account, the home country is a net exporter of MAN and importer of PRI output.

\section{A2: TCF-COSE Equilibrium}

Output for each good in each country is given by:

$$
\begin{aligned}
& x_{i}=\delta-\frac{L_{i}^{*}}{K}, \quad x_{i}^{*}=\delta+\frac{L_{i}^{*}}{K} \quad \text { and } \quad X_{i}=2 \delta \\
& y_{i}=\lambda R \frac{1}{K}, \quad y_{i}^{*}=0 \quad \text { and } \quad Y_{i}=\lambda R \frac{1}{K}
\end{aligned}
$$

The MAN incomes are now:

$$
\begin{aligned}
& I_{i}=\lambda R \frac{1}{2 K}+\frac{L_{i}^{*}}{K}\left[\lambda R-r_{i} K\right] \\
& I_{i}^{*}=\lambda R \frac{1}{2 K}-\frac{L_{i}^{*}}{K}\left[\lambda R-r_{i} K\right]
\end{aligned}
$$

Comparing the home income shares we get

$$
S_{i}^{y}-S_{i}^{x}=\frac{I_{i} x_{i}^{*}-I_{i}^{*} x_{i}}{Y_{i} X_{i}}>0
$$

since $x_{i}^{*}>x_{i}$ from (A8) and $I_{i}>I_{i}^{*}$ from (A10) and (A11). The home country is a net exporter of MAN and importer of PRI output.

\section{A3: TCF-COSE and TCFE-COSE Equilibrium}

The home MAN income is composed of the output of the home firms plus the output of the entrepreneurial migrants minus the interest payments on borrowed capital.

$$
\begin{aligned}
I_{e}=\lambda R \frac{1}{2 K}+n_{e}^{*} \lambda R-r_{e} L_{e}^{*} & =\lambda R \frac{1}{2 K}+n_{e}^{*}\left[\lambda R-r_{e} l_{e}^{*}\right] \\
& >\lambda R \frac{1}{2 K}+\frac{L_{i}^{*}}{K}\left[\lambda R-r_{i} K\right]=I_{i}{ }^{28}
\end{aligned}
$$

The foreign MAN income is composed of the output of the foreign FDI firms plus the interest income on loans to the home country

${ }^{28}$ From (21) and (18) $n_{e}^{*}=\frac{\Delta B}{r_{e}}=\frac{\Delta B[K-\delta]}{\gamma}>\frac{\Delta B[K-\delta]}{\gamma+\gamma^{*}+\Delta \lambda}=\frac{L_{i}^{*}}{K}$, and $r_{e} l_{e}^{*}=\frac{2 \gamma-\Delta B}{2}<\frac{2 \gamma-\Delta B}{2} \frac{K-\delta}{K}=r_{i} K$. 


$$
I_{e}^{*}=\lambda R\left[\frac{1}{2 K}-n_{e}^{*}\right]+r_{e} L_{e}^{*}=\lambda R \frac{1}{2 K}-n_{e}^{*}\left[\lambda R-r_{e} l_{e}^{*}\right]<I_{e}
$$

since $I_{e}+I_{e}^{*}=I_{i}+I_{i}^{*}, I_{e}>I_{i}$ implies $I_{e}^{*}<I_{i}^{*}$. Then

$$
S_{e}^{y}=\frac{I_{e}}{Y_{e}} \quad \text { and } \quad S_{e}^{x}=\frac{\delta}{2 \delta} \quad \text { and } \quad S_{e}^{y}-S_{e}^{x}=\frac{n_{e}^{*} \lambda R-r_{e} L_{e}^{*}}{Y_{e}}>0
$$

The home country remains an exporter of MAN, because it has had an inflow of factors specific to MAN output. While we have shown in the text that entrepreneurial migration (partially) substitutes for FDI, there are no clear substitutability or complementarity relationships between entrepreneurial migration and goods trade or international borrowing and lending. The home country has a larger income share of both MAN and PRI compared to the TCF-COSE. ${ }^{29}$ Borrowing by the home country, which is equal in value to the borrowing by its immigrant entrepreneurs, may be greater or less than its borrowing in the TCF-COSE. ${ }^{30}$

\section{A4: TCF-POSE and TCFE-COSE Equilibrium}

Home (including migrant) MAN income increases

$$
I_{e}-I_{i}=n_{e}^{*}\left[\lambda R-r_{e} l_{e}^{*}\right]-\frac{L_{i}^{*}}{K}[\lambda R-K]>0
$$

since $n_{e}^{*}>\frac{L_{i}^{*}}{K}$ and $K>r_{e} l_{e}^{*}$ in this range. ${ }^{31}$ But foreign MAN income could rise or fall.

$$
I_{e}^{*}-I_{i}^{*}=\left\{\frac{1}{2 K}-\left[1-A_{i}^{*}\right]\right\}[\lambda R-K]-n_{e}^{*}\left[\lambda R-r_{e} l_{e}^{*}\right]
$$

Once again there is no clear substitutability or complementarity relationship between entrepreneurial migration and goods trade or international borrowing and lending.

\footnotetext{
${ }^{29}$ We find using (27) and (A13) that $S_{e}^{y}-S_{i}^{y}=\frac{I_{e}-I_{i}}{Y_{e} Y_{i}}>0$ and $S_{e}^{x}=\frac{\delta}{2 \delta}>\frac{x_{i}}{2 \delta}=S_{i}^{x}$.

${ }^{30}$ Since $n_{e}^{*} l_{e}^{*}=\frac{\Delta B}{\gamma}\left[1-\frac{\Delta B}{2 \gamma}\right][K-\delta]^{2}$ and $\frac{L_{i}^{*}}{K}=\frac{\Delta B}{2 \gamma-\Delta B}[K-\delta], \operatorname{sign}\left\{\frac{n_{e}^{*} l_{e}^{*}-L_{i}^{*}}{k}\right\}=\operatorname{sign}\left\{\frac{K-\delta}{2 K}-2\left[\frac{\gamma}{2 \gamma-\Delta B}\right]^{2}\right\}$, which tends to be negative when $\Delta B$ is small.

${ }^{31} n_{e}^{*}-\frac{L_{i}^{*}}{K}=[K-\delta]+\Delta B \frac{[K-\delta]}{\gamma}-\gamma>[K-\delta]+\frac{\Delta B}{2}-\gamma>0 ;$ and $r_{e} l_{e}^{*}=\gamma-\frac{\Delta B}{2}<K-\delta<K$.
} 
Table 1: A Sample of Entrepreneurial Migration Schemes

\begin{tabular}{|c|c|c|c|}
\hline Country & Programme & Entry Requirements & Criteria for Permanent Stay \\
\hline Australia** & $\begin{array}{l}\text { Business innovation and } \\
\text { investment visa } \\
\text { (subclass 188) }\end{array}$ & $\begin{array}{l}\text { Applicants must be State or Territory nominated, under } 55 \\
\text { years of age, demonstrate } \$ A 800,000 \text { business and personal } \\
\text { Assets and meet a points test }\end{array}$ & $\begin{array}{l}\text { After } 4 \text { years employ } 2 \text { Australians and } \\
\text { asset requirements. }\end{array}$ \\
\hline $\begin{array}{l}\text { Canada } \\
\text { (Quebec Province) }\end{array}$ & $\begin{array}{l}\text { Entrepreneur } \\
\text { programme }\end{array}$ & $\begin{array}{l}\text { Assets of } \$ C 300,000+, \text { business experience, submit a } \\
\text { business proposal or have acquired a business. }\end{array}$ & $\begin{array}{l}\text { In } 3 \text { years create at least } 1 \text { job for } \\
\text { another Quebec resident }\end{array}$ \\
\hline France** & Entrepreneur Visa & Long term non-speculative investment of $€ 10$ million & 10 year residency permit \\
\hline Germany* & Self-employment Visa & $\begin{array}{l}\text { Invest } € 250,000 \text {. Investment not mandatory if have a strong } \\
\text { business idea and have enough capital to start. }\end{array}$ & Create 5 jobs within 3 years \\
\hline Ireland*** & Startup Visa & $\begin{array}{l}\text { Raise } € 75,000 \text { in startup capital for business deemed to have } \\
\text { "high potential" in export-oriented industries or fields } \\
\text { associated with innovation. }\end{array}$ & $\begin{array}{l}5 \text { year renewable, no residency } \\
\text { required }\end{array}$ \\
\hline Italy *** & Startup Visa & $\begin{array}{l}\text { Have } € 50,000 \text { in startup capital, submit innovative business } \\
\text { plan. }\end{array}$ & 2 year renewable \\
\hline New Zealand** & $\begin{array}{l}\text { Entrepreneur } \\
\text { work visa (introduced } \\
24 / 03 / 2014 \text { ) }\end{array}$ & $\begin{array}{l}\text { Invest } \$ 100,000 \text { in a NZ business; meet a points } \\
\text { Test; have business experience relevant to business proposal }\end{array}$ & 2 years residence \\
\hline Singapore** & $\begin{array}{l}\text { Global Investor } \\
\text { Programme }\end{array}$ & $\begin{array}{l}\text { Invest } \$ 2.5 \text { million over } 5 \text { years; minimum of } 3 \text { years } \\
\text { substantial business experience in a business with sufficient } \\
\text { turnover }\end{array}$ & Direct to permanent \\
\hline $\begin{array}{l}\text { United } \\
\text { Kingdom*** }\end{array}$ & Entrepreneur Visa. & $\begin{array}{l}\text { Have disposable funds depending on visa type; meet a } \\
\text { points test and English Requirement }\end{array}$ & After 5 years, residency and $10 \mathrm{FT}$ jobs \\
\hline United States** & $\begin{array}{l}\text { New Commercial } \\
\text { Enterprise and } \\
\text { EB5 Immigrant } \\
\text { visa }\end{array}$ & $\begin{array}{l}\text { Invest } \$ 1 \text { million (or } \$ 500,00 \text { if invest in targeted } \\
\text { employment area) }\end{array}$ & $\begin{array}{l}\text { After } 2 \text { years } 10 \mathrm{FT} \text { jobs and involved in } \\
\text { management }\end{array}$ \\
\hline
\end{tabular}

Sources: *Table 1 in Sumption (2012). **Australian Department of Immigration and Border Protection, Submission 14 to the Joint Standing Committee on Migration Inquiry into the Business Innovation and Investment Programme, 2014. Appendix F. ${ }^{* * *}$ Migreat.com. http://blog.migreat.com/2014/07/22/starta-company-in-europe-the-10-best-visa-options-for-entrepreneurs-and-startups/accessed24/11/2014 


\section{Appendix: (Not Intended for Publication)}

\section{Trade and Capital Mobility}

We now consider international trade flows and international borrowing and lending between two such economies. We deal with these transactions simultaneously because their effects are familiar from the literature. The resulting equilibrium will provide a base from which we can add FDI and then entrepreneurial migration. We assume the two countries have the same distributions of wealth and population, but that the home country has superior institutions stronger property rights $\left(\lambda>\lambda^{*}\right)$ and better corporate governance $\left(B^{*}>B\right)$, where foreign country variables and parameters are denoted by *. We start from an autarky equilibrium where one country is financially constrained and the other is not. Given that the distribution of asset holdings is assumed to be the same in the two countries, the home country has more eligible entrepreneurs at any common interest rate (see (12) below), so that if only one country is financially constrained it must be the foreign country. Then from (2)

$$
A_{f}=K-\gamma<A_{f}^{*}=K-\gamma^{*} \text { and } A_{w}=A_{w}^{*}=\delta
$$

An autarky equilibrium where the foreign country has a POSE and the home country a COSE is possible as long as

$$
1-A_{f}>\frac{1}{2 K}>1-A_{f}^{*} \quad \text { or } \quad \gamma>K-\delta>\gamma^{*}
$$

The first inequality implies the home country has a 'surplus' of eligible entrepreneurs when its interest rate is unity, and hence the home country's equilibrium interest rate under autarky exceeds the lower bound $\left(r_{a}>1\right)$ to ration the investment opportunities. The second inequality implies that the foreign country has a 'shortage' of eligible entrepreneurs even when its interest rate is at its lower bound $\left(r_{a}^{*}=1\right)$. We illustrate the possible autarky outcomes in Figure 1. Since we assume $\gamma>\gamma^{*}$, the relevant range is under the $45^{\circ}$ line, and can be divided into three areas. When both pledges are low (both $<K-\delta$ ), both countries are in a POSE; when both pledges are high (both $>K-\delta$ ), both countries are in a COSE, and in the intermediate ranges $\left(\gamma>K-\delta>\gamma^{*}\right)$ the home country has a COSE and the foreign a POSE.

Given $K$ and the distribution of wealth, $K-\delta\left(=K-A_{w}\right)$ measures the minimum pledge necessary for there to be sufficient eligible entrepreneurs to employ all the available capital under the advanced technology. From (4) we get

$$
r_{a}=\frac{\gamma}{K-\delta}>r_{a}^{*}=1
$$


where to the right of the first equality sign we have the ratio of the maximum to the minimum pledge.

International trade will equalise relative product prices (at $P_{c}$, say) and international capital movements will equalise interest rates (at $r_{c}$, say). From (1) we see that at the common interest rate we have

$$
A_{c}^{*}-A_{c}=\frac{1}{r_{c}}\left\{\gamma-\gamma^{*}\right\}>0
$$

that is the home country has the lower threshold because of its more efficient institutions (its higher pledge). Since trade alone does not affect interest rates in this model, ${ }^{32}$ once international borrowing and lending are possible capital will flow from the foreign to the home country until both interest rates are equalised at $r_{c} \geq 1$, with the inequality holding if the capital outflow releases the foreign country from its financial constraint before the home interest rate has fallen to unity. Let the amount lent by the foreign country be $L_{c}^{*}$. The new thresholds and interest rate must satisfy

$$
\begin{array}{ll}
A_{c}=K-\frac{1}{r_{c}} \gamma \quad \text { and } & A_{c}^{*}=K-\frac{1}{r_{c}} \gamma^{*} \\
1-A_{c}=\frac{1}{2 K}+\frac{L_{c}^{*}}{K} & \text { and } \quad 1-A_{c}^{*} \leq \frac{1}{2 K}-\frac{L_{c}^{*}}{K}
\end{array}
$$

The inequality in (14) holds if the equalised interest rate is unity, and we deal with this (TCPOSE) equilibrium first.

\subsection{TC-POSE Equilibrium}

When $r_{c}=1$, we can substitute (13) into (14) and solve for

$$
\begin{aligned}
& A_{c}=K-\gamma<\delta=A_{a} ; \quad A_{c}^{*}=K-\gamma^{*}=A_{a}^{*} \\
& \frac{L_{c}^{*}}{K}=\gamma-[K-\delta] \leq[K-\delta]-\gamma^{*}
\end{aligned}
$$

This TC-POSE equilibrium holds if $2[K-\delta] \geq \gamma+\gamma^{*}$, i.e. if $\frac{1}{K} \geq\left[K-A_{f}\right]+\left[K-A_{f}^{*}\right]$ so that there are insufficient eligible entrepreneurs in both countries combined to employ all the capital under the advanced technology, even when the equalised interest rate is unity.

\footnotetext{
${ }^{32}$ In our model international trade has no effect on the interest rate because the marginal product of capital is constant. In models where trade affects the marginal product of capital, as for example in Furusawa and Yanagawa (2011), the interest rate will increase in the country with the higher quality financial institutions and decline in the other country thus reinforcing the results of this model.
} 
This outcome is illustrated for point $U$ in Figure 2. The capital movement simultaneously relaxes the home wealth constraint and reduces the foreign entrepreneurial shortage. The home minimum pledge increases with its capital inflow (i.e. the vertical constraint moves to $\left.[K-\delta]+\frac{L_{c}^{*}}{K}\right)$ and the foreign minimum pledge falls due to its capital outflow (the horizontal constraint falls to $[K-\delta]-\frac{L_{C}^{*}}{K}$ ). For a point such as $\mathrm{U}$, the capital movement reduces the home interest rate to unity before removing the foreign entrepreneurial shortage and now both countries are in a POSE.

The capital inflow to the home country increases its number of active entrepreneurs, which reduces PRI output and increases MAN output. The capital outflow from the foreign country reduces its production of MAN using the safe technology, but in this case is insufficient to eliminate its entrepreneurial shortage and hence has no effect on its entrepreneurial threshold or PRI output. So:

$$
\begin{aligned}
& x_{c}=A_{c}=K-\gamma<\delta=x_{a} \text { and } x_{c}^{*}=A_{c}^{*}=K-\gamma^{*}=x_{a}^{*} \\
& X_{c} \equiv x_{c}+x_{c}^{*}=2 K-\left[\gamma+\gamma^{*}\right]<X_{a} \equiv x_{a}+x_{a}^{*} \\
& y_{c}=\lambda R\left[\frac{1}{2 K}+\frac{L_{c}^{*}}{K}\right]>\lambda R \frac{1}{2 K}=y_{a} \text { and } y_{c}^{*}=y_{a}^{*}-L_{c}^{*}<y_{a}^{*} \\
& Y_{c}=\frac{1}{2 K}\left[\lambda R+\lambda^{*} R\right]+\frac{L_{c}^{*}}{K}[\lambda R-K]-\left\{\frac{1}{2 K}-\left[1-A_{c}^{*}\right]\right\}\left[\lambda^{*} R-K\right]>Y_{a}
\end{aligned}
$$

The second term on the RHS of (20) represents the gain in output from employing $L_{c}^{*}$ under the advanced technology in the home country rather than the safe technology in the foreign country; while the third term reflects the output forgone because there is still an entrepreneurial shortage in the foreign country. Aggregate output of MAN increases because $L_{c}^{*}$ is now employed using the home advanced technology rather than the foreign safe technology.

The equilibrium world relative price is given by $\widetilde{P}_{c}=\frac{Y_{c}}{X_{c}}$. The home country will export MAN if its (income) share of world MAN output exceeds its (income) share of world PRI output $\left(S_{c}^{y}>S_{c}^{x}\right) \cdot{ }^{33}$ Home income from MAN $\left(I_{c}\right)$ is equal to home MAN output less the interest payments to foreign lenders - i.e. $I_{c}=y_{c}-L_{c}^{*}$. Foreign income from MAN $\left(I_{c}^{*}\right)$ is foreign MAN output plus interest income - i.e. $I_{c}^{*}=y_{c}^{*}+L_{c}^{*}=y_{a}^{*}$. So $S_{c}^{y}=\frac{y_{c}-L_{c}^{*}}{y_{c}-L_{c}^{*}+y_{a}^{*}}$.

\footnotetext{
${ }^{33} \mathrm{We}$ assume that the interest income on foreign loans and income earned from FDI is remitted in units of MAN the output that the capital/FDI produces. Once we take this repatriated income into account, it is the home income share rather than its output share that determines the direction of trade in goods.
} 
Likewise from (17) and (18) the home share of PRI income is $S_{C}^{x}=\frac{[K-\gamma]}{\left[K-\gamma+K-\gamma^{*}\right]}$. This then gives us

$$
S_{c}^{y}-S_{c}^{x}=\frac{\left[K-\gamma^{*}\right]\left[y_{c}-L_{c}^{*}\right]-[K-\gamma] y_{a}^{*}}{Y_{c} X_{c}}>0
$$

since $\gamma>\gamma^{*}$ and using $y_{c}-L_{c}^{*}>y_{a}^{*}$ from (19). The capital importing home country exports MAN and imports PRI. ${ }^{34}$ Our model thus replicates the standard trade pattern found in the literature. ${ }^{35}$

\subsection{TC-COSE Equilibrium}

Where the capital outflow eliminates the foreign entrepreneurial shortage before the home interest rate falls to unity, the TC-equilibrium is a COSE for both countries, and $r_{c}>1$. Making the same substitutions as above we obtain

$$
\begin{aligned}
& K-\delta+\frac{L_{c}^{*}}{K}=\frac{\gamma}{r_{c}}<\gamma \\
& K-\delta-\frac{L_{c}^{*}}{K}=\frac{\gamma^{*}}{r_{c}}<\gamma^{*} \\
& A_{c}=\delta-\frac{L_{c}^{*}}{K}<\delta=A_{a} \text { and } A_{c}^{*}=\delta+\frac{L_{c}^{*}}{K}>K-\gamma^{*}=A_{a}^{*} 36 \\
& \frac{L_{c}^{*}}{K}=\frac{\gamma-\gamma^{*}}{\gamma+\gamma^{*}}[K-\delta] \text { and } r_{c}=\frac{\gamma+\gamma^{*}}{2[K-\delta]}>1 \text { where } r_{a}=\frac{\gamma}{[K-\delta]}>r_{c}
\end{aligned}
$$

The equilibrium solution corresponding to initial point $\mathrm{V}$ is shown by point $\mathrm{Z}$ in Figure $2 .{ }^{37}$ This time the capital outflow reduces the foreign minimum pledge to $\gamma^{*}$ (thereby eliminating

\footnotetext{
${ }^{34}$ By considering trade and capital flows separately one can also show that the home country exports MAN when only goods trade is possible and that trade and capital movements are complements in that the income share of the home country in MAN increases and its PRI share declines, implying an increase in MAN exports, when we add capital movements to trade. It is well known in competitive trade models, that trade flows and capital flows are substitutes when comparative advantage arises because of differences in endowments. In contrast, when comparative advantage arises because of differences in technologies, trade flows and capital flows are complements. In our model, as in Antras and Caballero (2009) and Furusawa and Yanagawa (2011), when the only difference between countries is the quality of institutions, trade flows and capital flows are complements, implying that differences in the quality of the financial systems are equivalent to differences in technology. Pledgeable income per investment is $(\lambda R-B)$ and thus an improvement in technology (increase in $R$ ) or an improvement in the efficiency of institutions (increase in $\lambda$ or decrease in $B$ ) have exactly the same effect on the ability of the entrepreneur to raise external funds.

${ }^{35}$ See footnote 9 for theoretical analyses and footnote 10 for empirical evidence.

${ }^{36}$ Since $A_{c}^{*}=K-\frac{\gamma^{*}}{r_{c}}>K-\gamma^{*}=A_{a}^{*}$.

${ }^{37}$ If we let $\mathrm{z}=K-\delta+\frac{L_{c}^{*}}{K}$ and $z^{*}=K-\delta-\frac{L_{c}^{*}}{K}$, then taking the ratio of (22) to (23), we have $\frac{z^{*}}{z}=\frac{\gamma^{*}}{\gamma}$, so that the solution must lie on ray OV. Further $z+z^{*}=2[K-\delta]$, so that the solution must also lie on $C^{*} C$. The intersection of these two lines is point $\mathrm{Z}$.
} 
the foreign entrepreneurial shortage) before the capital inflow increases the home minimum pledge to $\gamma$ (thereby setting $r=1$ ). The capital flow then continues until interest rates are equalised in the two markets. ${ }^{38}$

Relative to autarky, the home entrepreneurial threshold has fallen, indicating a reduction in PRI output. The opposite has occurred in the foreign country. Using (24) we can show that

$$
x_{c}=\delta-\frac{L_{c}^{*}}{K}<\delta=x_{a} \text { and } x_{c}^{*}=\delta+\frac{L_{c}^{*}}{K}>K-\gamma^{*}=x_{a}^{*}
$$

But aggregate PRI output has fallen $\left(X_{c}=2 \delta<X_{a}\right.$ ). Home MAN output increases due to the capital inflow and induced reduction in its entrepreneurial threshold. Foreign MAN output falls, due to its capital outflow and increased entrepreneurial threshold. Aggregate MAN output increases because of the (partial) reallocation of capital to more efficient home producers. Let $\Delta \lambda \equiv\left[\lambda-\lambda^{*}\right] R$ measure the (expected) gain in output from being subject to the home rather than the foreign property rights regime, then

$$
y_{c}=\lambda R\left[\frac{1}{2 K}+\frac{L_{c}^{*}}{K}\right]>y_{a} \text { and } y_{c}^{*}=\lambda^{*} R\left[\frac{1}{2 K}-\frac{L_{c}^{*}}{K}\right]=\frac{1}{2}-L_{c}^{*}+\left[1-A_{c}^{*}\right]\left[\lambda^{*} R-K\right]<y_{a}^{*}
$$

Aggregate output $Y_{c}=\frac{1}{2 K}\left[\lambda R+\lambda^{*} R\right]+\frac{L_{c}^{*}}{K} \Delta \lambda$ has increased as

$$
Y_{c}-Y_{a}=\left\{\frac{1}{2 K}-\left\{1-A_{a}^{*}\right\}\right\}\left[\lambda^{*} R-K\right]+\frac{L_{c}^{*}}{K} \Delta \lambda>0
$$

To determine the direction of trade, we note that

$$
\begin{aligned}
& I_{c}=y_{c}-r_{c} L_{c}^{*}=\lambda R \frac{1}{2 K}+\frac{L_{c}^{*}}{K}\left[\lambda R-r_{c} K\right] \text { and } \\
& I_{c}^{*}=y_{c}^{*}+r_{c} L_{c}^{*}=\lambda^{*} R \frac{1}{2 K}-\frac{L_{c}^{*}}{K}\left[\lambda^{*} R-r_{c} K\right]
\end{aligned}
$$

If we compare the home country's income share of MAN relative to PRI, we find that

$$
S_{c}^{y}-S_{c}^{x}=\frac{I_{c} x_{c}^{*}-x_{c} I_{c}^{*}}{Y_{c} X_{c}}>0
$$

Since $I_{c}>I_{c}^{*}$ from (28) and $x_{c}^{*}>x_{c}$ from (26). So the capital-importing country also exports MAN in the TC-COSE equilibrium.

\footnotetext{
${ }^{38}$ The interest rate has adjusted to remove any surplus entrepreneurs in the combined markets. Note that $r_{c}-1=$ $\frac{\gamma+\gamma^{*}-2[K-\delta]}{2[K-\delta]}$, the proportional excess supply of entrepreneurs at a unitary interest rate.
} 